\title{
ChemComm
}

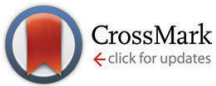

Cite this: Chem. Commun., 2015, 51,4666

Received 18th December 2014, Accepted 10th February 2015

DOI: $10.1039 / c 4 c c 10108 a$

www.rsc.org/chemcomm

\section{Real-time analysis of multiple anion mixtures in aqueous media using a single receptor $\dagger$}

\author{
Vaclav Havel, Mirza Arfan Yawer and Vladimir Sindelar*
}

\begin{abstract}
Bambusuril-based receptors have been used in conjunction with ${ }^{1} \mathrm{H}$ NMR spectroscopy to recognize mixtures of inorganic anions in aqueous solutions. This was achieved by examining complexationinduced changes in the receptors' ${ }^{1} \mathrm{H}$ NMR fingerprints. This approach enables the simultaneous identification of up to 9 anions and the quantification of up to 5 anions using a single receptor in $\mathrm{DMSO}^{-\mathrm{d}_{6}}$ containing $5 \% D_{2} \mathrm{O}$. Toxic perchlorate was recognized and quantified at $0.1 \mu \mathrm{M}\left(1.8 \mathrm{ppb}, \mathrm{mol} \mathrm{mol}^{-1}\right)$ concentration in pure water.
\end{abstract}

The design and preparation of synthetic chemosensors that respond selectively to specific analytes is of fundamental importance for monitoring biochemical processes and environmental changes. ${ }^{1,2}$ Most of these processes take place in water which leads to development of synthetic receptors that can sense small organic molecules, metal cations, and inorganic anions in aqueous media. Despite its recent progress, sensing of inorganic anions in water remains a challenging task. ${ }^{3}$ Inorganic anions have higher energies of solvation than cations of similar sizes and exist only in certain $\mathrm{pH}$ ranges. ${ }^{4,5}$ It is therefore particularly difficult to create potent anion receptors that can overcome water-anion interactions. ${ }^{6-10}$ Recognizing mixtures of inorganic anions in water solution is even more problematic and systems for the analysis of such mixtures based on host-guest systems are rare. There is only one recently developed solution to this problem involving the use of receptor arrays. ${ }^{11-13}$ These arrays consist of multiple receptors, each of which responds more or less selectively to each anion. To the best of our knowledge, there is essentially no example of a single receptor molecule that would enable differentiation of multiple anion mixtures in aqueous media. Here we present such chemosensors, bambusuril derivatives BU-1 and BU-2 (Fig. 1), single receptors that enable the detection and quantification of mixtures of ${ }^{1} \mathrm{H}$ NMR-silent anions in an aqueous environment using ${ }^{1} \mathrm{H}$ NMR spectroscopy. Remarkably, this method

Department of Chemistry and RECETOX, Masaryk University, Kamenice 5, 62500 Brno, Czech Republic.E-mail: sindelar@chemi.muni.cz

$\dagger$ Electronic supplementary information (ESI) available: Details of the quantitative and qualitative ${ }^{1} \mathrm{H}$ NMR analyses together with full versions of all ${ }^{1} \mathrm{H}$ NMR spectra presented in the paper. See DOI: $10.1039 / \mathrm{c} 4 \mathrm{cc} 10108 \mathrm{a}$ allows sensing of iodide and perchlorate at submicromolar concentrations in pure $\mathrm{D}_{2} \mathrm{O}$ !

Bambusurils (BU) are macrocyclic anion receptors consisting of glycoluril units connected by a set of methylene bridges (Fig. 1). They are known to form stable inclusion complexes with organic and inorganic anions. ${ }^{6,14-17}$ The inclusion of an anion inside the BU cavity causes changes in the chemical shifts of the macrocycle's hydrogen atoms that can be followed by ${ }^{1} \mathrm{H}$ NMR spectroscopy. We have previously reported that the association of BU-1 and halides in chloroform at room temperature is slow on the NMR time scale. The slow exchange is accompanied by the presence of separate sets of signals for the free and bound macrocycles. ${ }^{17}$ This behavior is quite rare in interactions between anions and receptors. ${ }^{18-21}$ Based on these findings, we hypothesized that inorganic anions with different shapes and sizes that form stable complexes with bambusuril could be differentiated based on the unique ${ }^{1} \mathrm{H}$ NMR fingerprints of the complexed macrocycles in aqueous media.

To test this suggestion, we investigated the interactions of 12 anions with BU-1 in DMSO- $\mathrm{d}_{6}$ containing $5 \% \mathrm{D}_{2} \mathrm{O}$. The anions investigated in this work include environmental pollutants $\left(\mathrm{ClO}_{4}{ }^{-}\right.$, $\mathrm{CN}^{-}, \mathrm{ReO}_{4}{ }^{-}$, and $\left.\mathrm{NO}_{3}{ }^{-}\right)$, biologically active anions $\left(\mathrm{Cl}^{-}\right.$and $\left.\mathrm{HSO}_{4}{ }^{-}\right)$, and species used in ion-pairing catalysis $\left(\mathrm{BF}_{4}^{-}\right)$and lithium-ion battery designs $\left(\mathrm{PF}_{6}{ }^{-}\right)$. Analysis by ${ }^{1} \mathrm{H}$ NMR spectroscopy revealed that all of the selected anions induce similar behavior when added

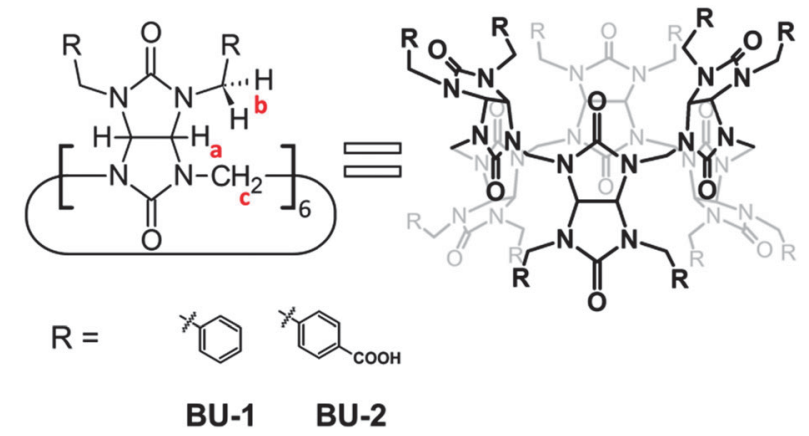

Fig. 1 Structures of tested bambusuril derivatives. 
to BU-1 solutions (Fig. 2, see ESI, $\dagger$ Fig. S1 for full spectra). The signals of the free and bound forms of the macrocycle were observed when less than 1 equiv. of the anion was added, demonstrating that anion exchange was slow on the NMR time scale. Moreover, when 1 equivalent of the anion was added to a submillimolar BU-1 solution, only signals corresponding to the anion-bound form of the macrocycle were detected. The observed NMR patterns are consistent with the formation of very stable host-guest complexes of $1: 1$ stoichiometry. This is in agreement with the $1: 1$ binding mode and high affinity $\left(>10^{5} \mathrm{M}^{-1}\right)$ previously determined for complexes of BU-1 with halides in chloroform. ${ }^{17}$

Fig. 2 illustrates the sensing potential of BU-1. First we measured the ${ }^{1} \mathrm{H}$ NMR spectrum of BU-1 in the absence of anions. NMR spectra were then acquired for the complexes of BU-1 with individual anions and their chemical shifts were compared. Fig. 2 clearly shows that the chemical shifts of the BU-1 protons are highly sensitive to the nature of the complexed anions. The most pronounced changes in chemical shifts following anion inclusion

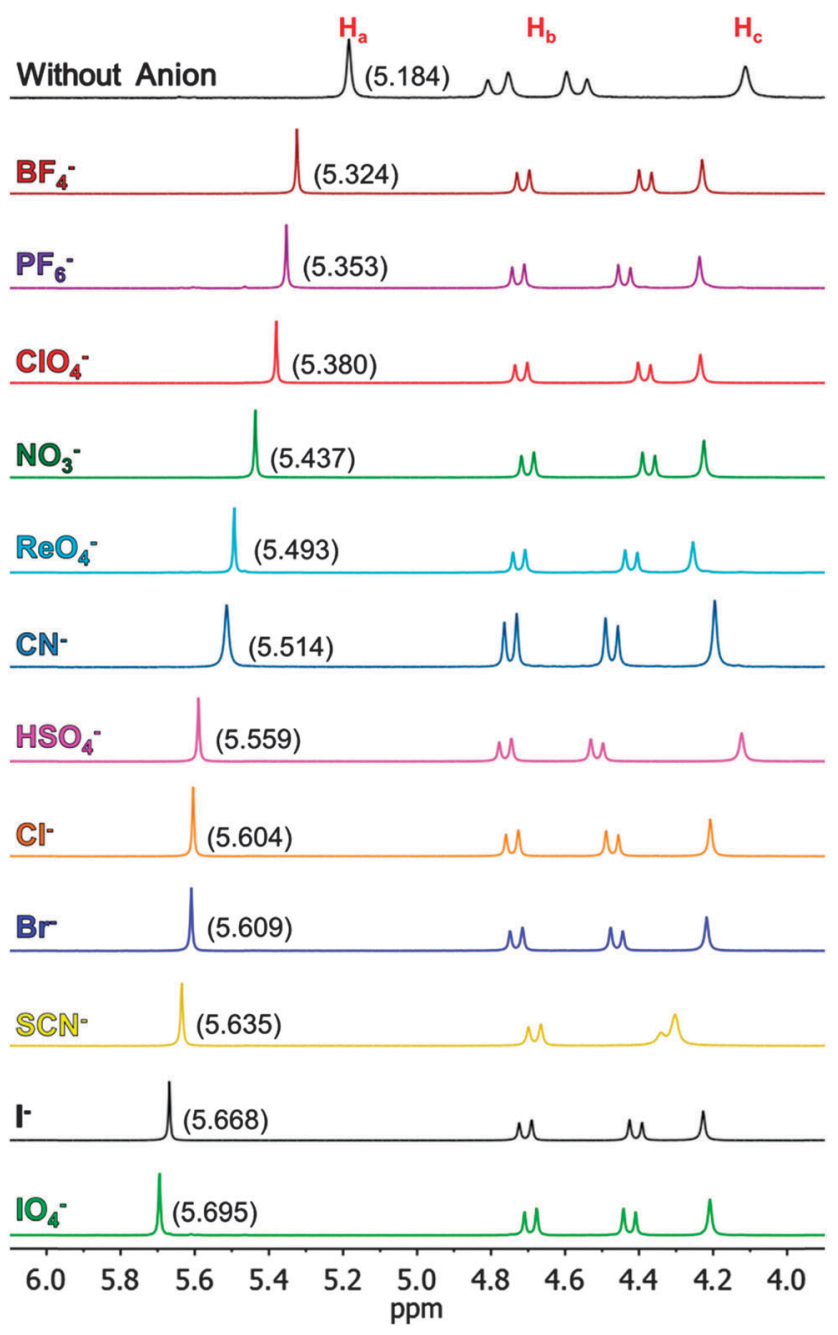

Fig. $2{ }^{1} \mathrm{H}$ NMR spectra $\left(500 \mathrm{MHz}, 5 \% \mathrm{D}_{2} \mathrm{O}-\mathrm{DMSO}-\mathrm{d}_{6}, 30{ }^{\circ} \mathrm{C}\right.$, TMS) of BU-1 $\left(c_{(\mathrm{BU}-1)}=1 \times 10^{-3} \mathrm{M}\right)$ in the absence and presence of 12 anions (in excess). The chemical shifts of the $\mathrm{H}_{\mathrm{a}}$ signals in each spectrum are given in brackets. Anions were added in the form of tetrabutylammonium (TBA) salts. were observed for the $\mathrm{H}_{\mathrm{a}}$ methine protons. The difference between $\mathrm{H}_{\mathrm{a}}$ signals for the anion-free macrocycle and the most downfield shifted complex is almost $0.51 \mathrm{ppm}$. If we consider only the most upfield shifted $\mathrm{H}_{\mathrm{a}}$ signals versus the most downfield shifted $\mathrm{H}_{\mathrm{a}}$ signal for bambusuril-anion complexes (complexes with $\mathrm{BF}_{4}{ }^{-}$ and $\mathrm{IO}_{4}{ }^{-}$anions), then the change drops slightly to $0.37 \mathrm{ppm}$. The macrocycle contains 12 such $\mathrm{H}_{\mathrm{a}}$ protons, which are located on its glycoluril building blocks and project into the center of the cavity. Most of the tested anions can be distinguished based on the chemical shift of the $\mathrm{H}_{\mathrm{a}}$ signal. However, some pairs of the anions $\left(\mathrm{Br}^{-}\right.$and $\mathrm{Cl}^{-} ; \mathrm{HSO}_{4}{ }^{-}$and $\left.\mathrm{Cl}^{-}\right)$cannot be distinguished based on the chemical shifts of these methine protons alone. In the case of the $\mathrm{HSO}_{4}{ }^{-}$and $\mathrm{Cl}^{-}$pair, discrimination can be achieved by considering the unique chemical shifts of the macrocycle's $\mathrm{H}_{b}$ and $\mathrm{H}_{c}$ protons following complex formation. Spectra of each complex were acquired at different concentrations $\left(10^{-3}-10^{-5} \mathrm{M}\right)$ at least three times, and the positions of the signals never changed by more than 0.005 ppm (Fig. S10, ESI $\dagger$ ).

Ability of BU-1 to sense anions in their individual aqueous solutions led us to challenge the macrocycle for qualitatively analyzing multi-anion mixtures. We found out that BU-1 is able to differentiate up to 9 anions in $5 \% \mathrm{D}_{2} \mathrm{O}-\mathrm{DMSO}-\mathrm{d}_{6}$. Amazingly, the signals characterizing complexes of BU-1 with anions in their mixtures were within $0.005 \mathrm{ppm}$ of their location in the corresponding isolated complexes and remained constant upon dilution from 6 to $0.01 \mathrm{mM}$ (Fig. 3). Please note that a similar approach for analyzing multi-component anion mixtures but performed in organic solvents was reported previously by Jeong and coworkers. ${ }^{21}$ Their indole-based receptor benefited from the changes in chemical shifts of $\mathrm{NH}$ protons induced by the hydrogen bonding interaction with anions. It is therefore unlikely that this system would function in aqueous media due to proton-deuterium exchange.

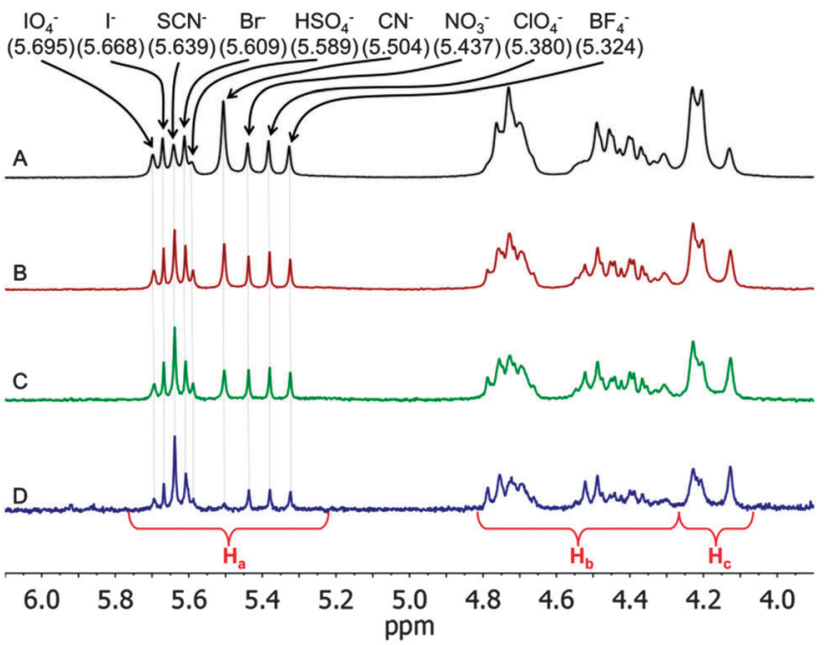

Fig. $3{ }^{1} \mathrm{H}$ NMR spectra $\left(500 \mathrm{MHz}, 5 \% \mathrm{D}_{2} \mathrm{O}-\mathrm{DMSO}-\mathrm{d}_{6}, 30{ }^{\circ} \mathrm{C}\right.$, TMS) of BU-1-anion mixtures at different concentrations: $(\mathrm{A}) \mathrm{C}_{(\mathrm{BU}-1)}=6 \times 10^{-3} \mathrm{M}$, $C_{(\mathrm{A})}=5 \times 10^{-4} \mathrm{M}$; (B) $C_{(B U-1)}=1.2 \times 10^{-3} \mathrm{M}, C_{(A)}=1 \times 10^{-4} \mathrm{M}$; (C) $C_{(B U-1)}=$ $6 \times 10^{-4} \mathrm{M}, C_{(\mathrm{A})}=5 \times 10^{-5} \mathrm{M}$; and (D) $C_{(B U-1)}=1.2 \times 10^{-4} \mathrm{M}, C_{(\mathrm{A})}=1 \times 10^{-5} \mathrm{M}$. $C_{(A)}$ is the concentration of individual anions in the solution. The chemical shifts of the $\mathrm{H}_{\mathrm{a}}$ signals in each spectrum are given in brackets. 
Quantitative NMR analysis is gaining more popularity, largely due to its universal applicability for organic substrates. ${ }^{22-24}$ Most quantitative NMR studies involve the direct observation of NMRactive nuclei within the studied molecules. This method can be used to determine the concentration and purity of agrochemicals, natural products or synthetic molecules. ${ }^{25,26}$ In addition, there is growing interest in chromatographic NMR spectroscopy and indirect NMR sensing based on supramolecular interactions between analytes and NMR-active receptors. ${ }^{27-29}$ However, NMR-based approaches have not previously been used to analyze complex mixtures of small inorganic anions in aqueous media. We therefore decided to investigate the potential of BU-1 to serve as an NMR-active quantitative chemosensor for analyzing multi-anion mixtures. We selected five anions $\left(\mathrm{I}^{-}, \mathrm{Br}^{-}, \mathrm{NO}_{3}{ }^{-}, \mathrm{ClO}_{4}^{-}\right.$, and $\left.\mathrm{BF}_{4}^{-}\right)$whose complexes with BU-1 are readily distinguished by ${ }^{1} \mathrm{H}$ NMR due to the very different chemical shifts of their $\mathrm{H}_{\mathrm{a}}$ protons (Fig. 4). Mixtures of these five species with individual anion concentrations of around $10^{-4} \mathrm{M}$ were added to an excess of BU-1. ${ }^{30}$ Peaks occurring between 5.6 and $5.2 \mathrm{ppm}$ in the mixtures' NMR spectra were confidently assigned to the complexes of BU with specific anions because their chemical shifts matched those observed on mixing BU-1 with solutions of single anions (within the experimental error). The methine signals corresponding to the individual anion complexes were well separated, enabling quantification of the anions. The concentrations of each anion could therefore be determined with an experimental error of less than $10 \%$. The table shows the agreement between the theoretical $\left(c_{\text {theor. }}\right)$ and measured $\left(c_{\text {calc. }}\right)$ anion concentrations. Dimethyl sulfone was used as an internal standard for the quantitative measurements. Anions were used in the form of their tetrabutylammonium salts. Qualitative and quantitative analyses with similar levels of certainty could also be performed using mixtures of the same anions in which the anion concentration ranged from $10^{-3}-10^{-4} \mathrm{M}$ (Fig. S3 and S4, ESI $\dagger$ ).

During the middle stages of this study, the bambusuril derivative BU-2 was prepared by our group. ${ }^{6}$ This compound is soluble in neutral and basic water at millimolar concentrations, which allowed us to evaluate the sensing ability of bambusurils in pure water.

We performed ${ }^{1} \mathrm{H}$ NMR experiments in $\mathrm{D}_{2} \mathrm{O}$ containing $20 \mathrm{mM}$ $\mathrm{K}_{2} \mathrm{DPO}_{4}$. pD of the solution was 7.1 when $1 \mathrm{mM}$ concentration of BU-2 was used. In contrast with DMSO- $\mathrm{d}_{6}$ containing $5 \% \mathrm{D}_{2} \mathrm{O}$ examined in this work, the binding of BU-2 to some anions appeared to be fast on the ${ }^{1} \mathrm{H}$ NMR time scale in $\mathrm{D}_{2} \mathrm{O}$ at $30{ }^{\circ} \mathrm{C}$.

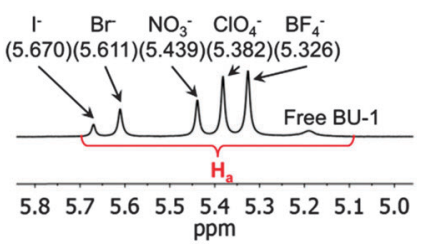

\begin{tabular}{|c|c|c|c|}
\hline $\mathrm{A}^{-}$ & $\begin{array}{c}c_{\text {(teor) }} \\
{[\text { mM] }}\end{array}$ & $\begin{array}{c}c_{\text {(calc.) }} \\
{[\text { mM] }}\end{array}$ & $\begin{array}{c}\text { Error } \\
{[\%]}\end{array}$ \\
\hline $\mathrm{BF}_{4}^{-}$ & 1.59 & 1.51 & 4.8 \\
\hline $\mathrm{ClO}_{4}^{-}$ & 1.31 & 1.24 & 5.6 \\
\hline $\mathrm{NO}_{3}^{-}$ & 0.829 & 0.789 & 4.8 \\
\hline $\mathrm{Br}$ & 0.571 & 0.599 & 4.9 \\
\hline $\mathrm{r}^{-}$ & 0.265 & 0.247 & 6.6 \\
\hline
\end{tabular}

Fig. $4{ }^{1} \mathrm{H}$ NMR spectra (500 MHz, 5\% $\mathrm{D}_{2} \mathrm{O}-\mathrm{DMSO}-\mathrm{d}_{6}, 30{ }^{\circ} \mathrm{C}$, TMS), of BU-1 in the presence of 5 anions showing their quantitative analysis. The inserted table shows the agreement between the theoretical $\left(c_{\text {theor }}\right)$ and measured $\left(c_{\text {calc. }}\right)$ anion concentrations. Dimethyl sulfone was used as an internal standard for the quantitative measurements. Anions were used in the form of their TBA salts.

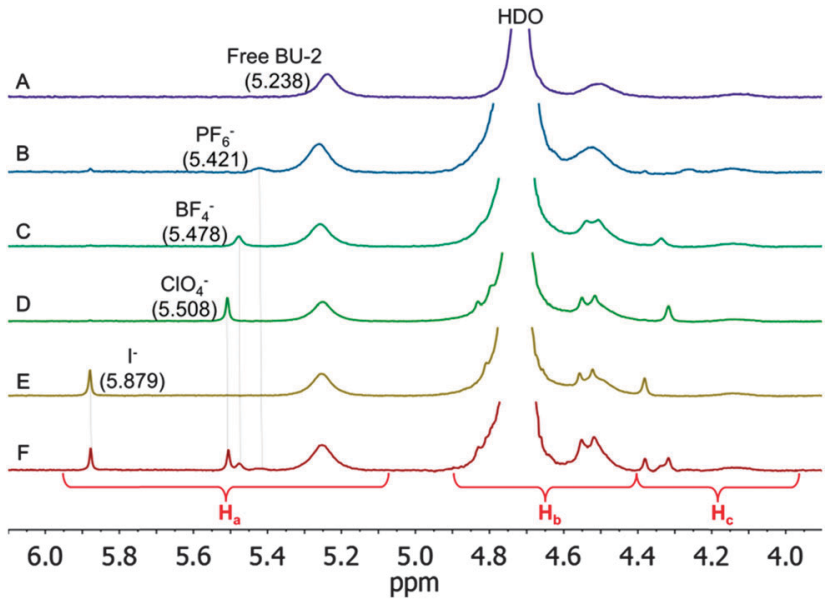

Fig. $5{ }^{1} \mathrm{H}$ NMR spectra $\left(500 \mathrm{MHz}, \mathrm{D}_{2} \mathrm{O}, 20 \mathrm{mM} \mathrm{K}_{2} \mathrm{DPO}_{4}, 30{ }^{\circ} \mathrm{C}\right)$ of $\mathbf{B U}-\mathbf{2}$ : $(A)$ in the absence of an anion, $(B-E)$ in the presence of specific anions, and $(\mathrm{F})$ in the presence of 4 anions. Concentrations of anions $\left(C_{(A)}=1.0 \times 10^{-5}\right.$ $\mathrm{M})$ and the macrocycle $\left(\mathrm{C}_{(\mathrm{BU}-2)}=1.0 \times 10^{-3} \mathrm{M}\right)$ were kept constant for all experiments. The chemical shifts of the $\mathrm{H}_{a}$ signals in each spectrum are given in brackets.

These anions, including $\mathrm{F}^{-}, \mathrm{Cl}^{-}, \mathrm{CN}^{-}, \mathrm{IO}_{4}^{-}$, and $\mathrm{ReO}_{4}{ }^{-}$, show lower affinity for BU-2 $\left(K_{\mathrm{a}}<3.0 \times 10^{4} \mathrm{M}^{-1}\right)$. On the other hand, the remaining anions $\left(\mathrm{Br}^{-}, \mathrm{NO}_{3}{ }^{-}, \mathrm{PF}_{6}{ }^{-}, \mathrm{BF}_{4}{ }^{-}, \mathrm{I}^{-}\right.$, and $\left.\mathrm{ClO}_{4}{ }^{-}\right)$ form stronger complexes with the macrocycle in a slow regime on the NMR time scale. Four of these strongly binding anions can be recognized upon inclusion in BU-2 by the unique position of the $\mathrm{H}_{\mathrm{a}}$ signal (Fig. 5A-E).

Nitrate was excluded from this experiment as the induced shift of the BU-2 $\mathrm{H}_{\mathrm{a}}$ signals upon complexation is similar to the one of $\mathrm{PF}_{6}{ }^{-}$. Unique NMR fingerprints of $\mathbf{B U}-2$ complexes with four anions enable qualitative analysis of their mixture (Fig. 5F). This is possible due to constant chemical shifts of individual complexes, which remained the same also in the anion mixture. Please note that the recognition of multi-anion mixtures was possible even at an anion concentration of $10^{-5} \mathrm{M}$ in $\mathrm{D}_{2} \mathrm{O}$. The height to width ratio of the $\mathrm{H}_{\mathrm{a}}$ signals of anions in their mixtures can be further improved by decreasing working temperature from 30 to $5{ }^{\circ} \mathrm{C}$ (Fig. S7 and S8, ESI $\dagger$ ). This is obvious particularly in the case of $\mathrm{Br}^{-}$in which case the $\mathrm{H}_{\mathrm{a}}$ signal is not visible at $30{ }^{\circ} \mathrm{C}$ but appears in the spectra recorded at $5{ }^{\circ} \mathrm{C}$.

On the other hand, $\mathrm{H}_{\mathrm{a}}$ signals for the $\mathbf{B U}-2$ complexes with $\mathrm{I}^{-}$and $\mathrm{ClO}_{4}{ }^{-}$remain sharp even at $30{ }^{\circ} \mathrm{C}$ and are well separated. Therefore, we investigated the quantitative sensing of $\mathrm{I}^{-}$ and $\mathrm{ClO}_{4}{ }^{-}$mixtures in $\mathrm{D}_{2} \mathrm{O}$ at $30{ }^{\circ} \mathrm{C}$ (Fig. 6). We started with $8 \mu \mathrm{M}$ concentrations of both anions in the form of tetramethylammonium (TMA) salts in the presence of $80 \mu \mathrm{M}$ BU-2 solution in $\mathrm{D}_{2} \mathrm{O}$ (Fig. 6A). The anion concentrations calculated from the integrated area of the $\mathrm{H}_{\mathrm{a}}$ signals agreed with the theoretical values within the experimental error. Remarkably, the detection of $\mathrm{I}^{-}$and $\mathrm{ClO}_{4}^{-}$was possible even at the individual anion concentrations as low as $0.1 \mu \mathrm{M}$ (Fig. 6C and D). ${ }^{31}$ Detection of such low concentrations of inorganic anions using the NMR technique is unprecedented not only for aqueous but also for any organic media. 


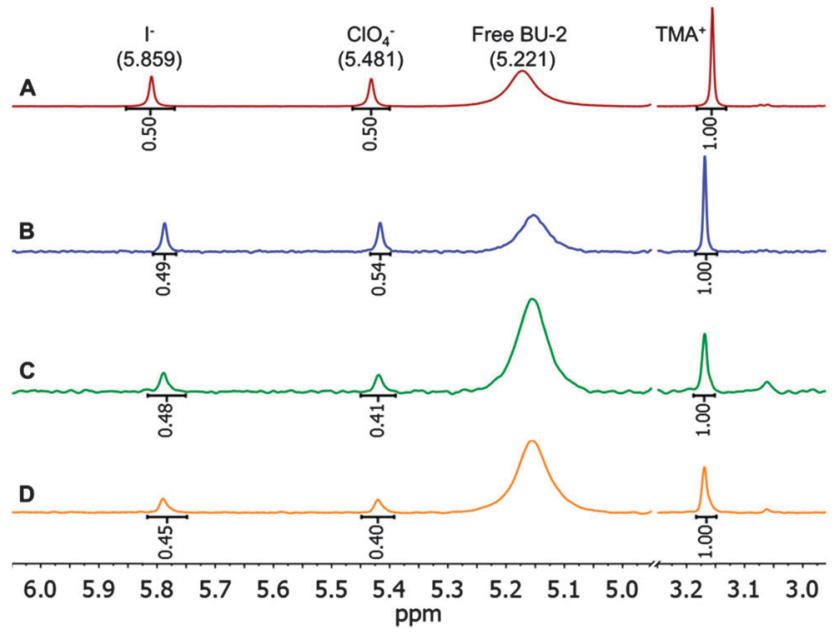

Fig. $6{ }^{1} \mathrm{H} \mathrm{NMR}\left(600 \mathrm{MHz}, \mathrm{D}_{2} \mathrm{O}, 20 \mathrm{mM} \mathrm{K}_{2} \mathrm{DPO}_{4}, 30{ }^{\circ} \mathrm{C}\right)$ spectra of $\mathrm{BU}-2$ in the presence of equimolar mixtures of iodide and perchlorate with decreasing anion concentrations $\left(C_{(A)}\right):(A) C_{(A)}=8 \times 10^{-6} \mathrm{M}, C_{(B U-2)}=$ $8 \times 10^{-5} \mathrm{M}, \mathrm{ns}=128,(\mathrm{~B}) \mathrm{C}_{(\mathrm{A})}=8 \times 10^{-7} \mathrm{M}, \mathrm{C}_{(\mathrm{BU}-2)}=8 \times 10^{-6} \mathrm{M}, \mathrm{ns}=128$, (C) $C_{(\mathrm{A})}=1 \times 10^{-7} \mathrm{M}, \mathrm{C}_{(\mathrm{BU}-2)}=1 \times 10^{-5} \mathrm{M}, \mathrm{ns}=128$ (D) $C_{(\mathrm{A})}=1 \times 10^{-7} \mathrm{M}$, $C_{(B U-2)}=1 \times 10^{-5} \mathrm{M}, \mathrm{ns}=1024$.

In conclusion, we have established a simple and straightforward approach for characterizing and quantifying mixtures of inorganic anions. This method relies on a single bambusuril receptor, BU-1 or BU-2, that forms stable 1:1 supramolecular complexes with 12 different anions by enclosing them in its central cavity. The anions' shapes and sizes influence the electron density in the vicinity of the macrocycle's hydrogen nuclei, giving each complex a unique ${ }^{1} \mathrm{H}$ NMR fingerprint. The sensing system described herein is the first that enables the characterization of complex mixtures of inorganic anions by NMR in aqueous media. Importantly, it relies entirely on standard ${ }^{1} \mathrm{H}$ NMR techniques and is capable of anion sensing at submicromolar concentrations even in pure $\mathrm{D}_{2} \mathrm{O}$.

This work was supported by the Czech Science Foundation (13-15576S) and the Czech Ministry of Education (projects LM2011028 and LO1214). V.H. acknowledges the Brno PhD Talent Scholarship program sponsored by Brno City Municipality. We thank Radovan Fiala of Josef Dadok National NMR Centre, CEITEC-Masaryk University, for the help with recording NMR spectra.

\section{Notes and references}

1 Chemosensors: principles, strategies, and applications, ed. B. Wang and E. V. Anslyn, Wiley, Hoboken, N.J, 2011.

2 K. L. Diehl and E. V. Anslyn, Chem. Soc. Rev., 2013, 42, 8596.

3 N. H. Evans and P. D. Beer, Angew. Chem., Int. Ed., 2014, 53, 11716-11754.
4 P. A. Gale, N. Busschaert, C. J. E. Haynes, L. E. Karagiannidis and I. L. Kirby, Chem. Soc. Rev., 2014, 43, 205.

5 P. A. Gale and C. Caltagirone, Chem. Soc. Rev., 2015, DOI: 10.1039/ C4CS00179F.

6 M. A. Yawer, V. Havel and V. Sindelar, Angew. Chem., Int. Ed., 2015, 54, 276-279.

7 M. Lisbjerg, B. M. Jessen, B. Rasmussen, B. E. Nielsen, A. Ø. Madsen and M. Pittelkow, Chem. Sci., 2014, 5, 2647-2650.

8 M. Lisbjerg, B. E. Nielsen, B. O. Milhøj, S. P. A. Sauer and M. Pittelkow, Org. Biomol. Chem., 2015, 13, 369-373.

9 F. Sommer and S. Kubik, Org. Biomol. Chem., 2014, 12, 8851-8860.

10 M. J. Langton, S. W. Robinson, I. Marques, V. Félix and P. D. Beer, Nat. Chem., 2014, 6, 1039-1043.

11 Y. Liu, M. A. Palacios and P. Anzenbacher, Chem. Commun., 2010, 46, 1860.

12 P. Anzenbacher, Y. Liu, M. A. Palacios, T. Minami, Z. Wang and R. Nishiyabu, Chem. - Eur. J., 2013, 19, 8497-8506.

13 M. A. Palacios, R. Nishiyabu, M. Marquez and P. Anzenbacher, J. Am. Chem. Soc., 2007, 129, 7538-7544.

14 J. Svec, M. Necas and V. Sindelar, Angew. Chem., Int. Ed., 2010, 49, 2378-2381.

15 J. Svec, M. Dusek, K. Fejfarova, P. Stacko, P. Klán, A. E. Kaifer, W. Li, E. Hudeckova and V. Sindelar, Chem. - Eur. J., 2011, 17, 5605-5612.

16 Á. Révész, D. Schröder, J. Svec, M. Wimmerová and V. Sindelar, J. Phys. Chem. A, 2011, 115, 11378-11386.

17 V. Havel, J. Svec, M. Wimmerova, M. Dusek, M. Pojarova and V. Sindelar, Org. Lett., 2011, 13, 4000-4003.

18 C. Jia, B. Wu, S. Li, X. Huang, Q. Zhao, Q.-S. Li and X.-J. Yang, Angew. Chem., Int. Ed., 2011, 50, 486-490.

19 K. J. Wallace, W. J. Belcher, D. R. Turner, K. F. Syed and J. W. Steed, J. Am. Chem. Soc., 2003, 125, 9699-9715.

20 M. Ménand and I. Jabin, Chem. - Eur. J., 2010, 16, 2159-2169.

21 K.-J. Chang, D. Moon, M. S. Lah and K.-S. Jeong, Angew. Chem., Int. Ed., 2005, 44, 7926-7929.

22 S. K. Bharti and R. Roy, TrAC, Trends Anal. Chem., 2012, 35, 5-26.

23 G. F. Pauli, T. Gödecke, B. U. Jaki and D. C. Lankin, J. Nat. Prod., 2012, 75, 834-851.

24 C. Simmler, J. G. Napolitano, J. B. McAlpine, S.-N. Chen and G. F. Pauli, Curr. Opin. Biotechnol., 2014, 25, 51-59.

25 G. del Campo, I. Berregi, R. Caracena and J. Zuriarrain, Talanta, 2010, 81, 367-371.

26 P. Zaragozá, J. L. Ruiz-Cerdá, G. Quintás, S. Gil, A. M. Costero, Z. León, J.-L. Vivancos and R. Martínez-Máñez, Analyst, 2014, 139, 3875.

27 P. D. Garimella, T. Meldrum, L. S. Witus, M. Smith, V. S. Bajaj, D. E. Wemmer, M. B. Francis and A. Pines, J. Am. Chem. Soc., 2014, 136, 164-168.

28 K. A. Heisel, Am. J. Anal. Chem., 2012, 03, 401-409.

29 C. Pemberton, R. E. Hoffman, A. Aserin and N. Garti, Langmuir, 2011, 27, 4497-4504.

30 Using the competitive ${ }^{1} \mathrm{H}$ NMR study and isothermal titration calorimetry, we found out that $\mathbf{B U}-\mathbf{1}$ binds $\mathrm{BF}_{4}{ }^{-}$with the lowest affinity out of the five tested anions with an association constant of $2.2 \times 10^{5} \mathrm{M}^{-1}$ (see ESI $\dagger$ ). Saturated solutions of BU-1 were used for quantitative NMR analysis. High affinity of BU-1 together with excess of the macrocycle guarantees a quantitative anion binding during the analysis.

31 The association constant of $\mathbf{B U}-2$ with $\mathrm{I}^{-}$and $\mathrm{ClO}_{4}{ }^{-}$under the experimental conditions are $1.0 \times 10^{7} \mathrm{M}^{-1}$ and $5.5 \times 10^{7} \mathrm{M}^{-1}$, respectively. ${ }^{[6]}$ This means that anion binding is almost quantitative (99.0 and $99.8 \%$ ) even at $0.1 \mu \mathrm{M}$ anion and $10 \mu \mathrm{M}$ BU-2 concentrations. 